УДК 72.01

\title{
Н.Г. Багдасарьян
}

\section{Архитектор в социокультурном пространстве города}

\section{Аннотация:}

Опираясь на тезис Г. Зиммеля о необходимости поиска ответа на вопрос о жизни больших городов, который лежит в плоскости соотношения между индивидуальным и надиндивидуальным содержанием жизни, автор ведет речь о требованиях к современной архитектуре. Город рассматривается через призму социальности и соответствующих требований к профессиональным характеристикам архитектора. Подчеркивается значимость междисциплинарного подхода к образовательному процессу в высшей архитектурной школе, роль социально-философского и культурологического знания.

Ключевые слова: Зиммель, социальное пространство города, компетентность архитектора, ценности и установки

Об авторе: Багдасарьян Надежда Гегамовна, доктор философских наук, профессор, МГТУ им. Н.Э. Баумана, профессор кафедры «Социология и культурология» факультета социальных и гуманитарных наук, Государственный университет «Дубна», заведующий кафедрой социологии и гуманитарных наук факультета социальных и гуманитарных наук; эл. почта: ngbagda@mail.ru

По прогнозам ООН, через 150 лет $30 \%$ площуад земель мира будут городскими ландшафтами.

Георг Зиммель в работе «Большие города и духовная жизнь», написанной в 1902 г., отмечал: «Всюду, где идет речь о внутреннем содержании результатов специфической современной жизни, где, так сказать, тело культуры спрашивает о своей душе, - каковой вопрос нас сейчас занимает по отношению к большим городам, - всюду ответ нужно искать в том уравнении, которое составляется между индивидуальным и надиндивидуальным содержанием жизни, - в приспособляемости личности, благодаря которой она уживается с внешними силами» $[3$, с. 1]. Как это почти всегда бывает с 
мыслителями такого уровня, как Зиммель, эта формула обрела универсальный характер, позволяя в каждую эпоху соотносить с ней наличное бытие. Разумеется, и сама «типовая» личность, и те внешние силы, к которым она должна приспособиться, кардинально преобразились за минувшие с момента написания работы сто с лишним лет. Однако уравнение это продолжает «работать», став методологической основой выявления законов жизни человека в большом городе.

Современный архитектор - при самых невообразимых его творческих изысках, при самом фантастическом полете его фантазии - не может не учитывать в качестве исходной, фундаментальной позиции оба среза того пространства, в котором он творит. Один срез обусловлен индивидуальным, антропологическим измерением большого города, другой измерением социальным. Сложность профессиональной саморепрезентации архитектора в необходимости соотнесения этих пластов, которые, порой, находятся не столько в системе взаимодополнительности, сколько - и в большей степени - в оппозиции друг к другу.

Город - поле столкновения и конфликта, борьбы и сотрудничества, присвоения и вытеснения. Город - это отпечаток социального пространства в пространстве физическом. В нем параллельно идут процессы разрыва традиционных социальных связей (о которых писали классики европейской социологии города) и - «сборка» новых социальных общностей. Такие общности традиционно формировались в зависимости от географических факторов, производственной и этнической топологии. Однако техногенная цивилизация меняет сам процесс генезиса и трансформации современных городов. В разрастающихся территориально городах становится все труднее сочетать интересы и потребности личности в обустройстве индивидуального жизненного пространства, в организации жизни семьи, состоящей из двух, или даже трех поколений, и выстраивании профессиональной карьеры, в выборе соответствующего статусу человека места работы и в реализации спортивных, художественных и иных увлечений.

Пространство города все в меньшей мере становится территорий безопасности. В частности, Москва, по результатам ежегодного опроса компании Мерсер, называлась в числе наиболее опасных и смертоносных мировых метрополисов с точки зрения своих экологических стандартов. В одном из рейтингов Москва заняла 14-е место в списке самых грязных городов мира. По уровню привлекательности среди иностранцев город занял 48-е место из 60 (Global Market Insight, 2011). А по качеству жизни у Москвы - 166-е место среди других городов мира [Цит. по 7, с. 40]. 
Как в любой социотехнической системе, по мере ее усложнения, возрастают риски и техногенных, и социальных катастроф. В данном случае мы используем понятие катастрофы вовсе не метафорически. Напомним, что термин «теория катастроф», введенный математиками Р. Томом и К. Зиманом на рубеже 1960-х-1970-х гг., оказался как нельзя кстати для понимания не только бифуркации дифференциальных уравнений в динамических системах, но и для анализа и прогнозирования любых иных динамических систем - как природного свойства (радуга, иные типы каустиков, в том числе связанных с крупномасштабной структурой вселенной), так и социальных явлений (бунты в тюрьмах, протестные движения и пр.) [1].

«Теория катастроф» предоставила социальным исследователям достоверный и убедительный инструмент для моделирования разнообразных процессов, происходящих в обществе - и на уровне микро-, и на уровне макроизменений. Используя этот инструментарий, мысля город как сложную социотехническую систему, выделим две группы параметров, определяющих ее состояние: параметры внешние и внутренние. Предположим, что внешние параметры определяются географической локализацией города, предопределяющей климат, ландшафт, наличие природных ресурсов, хозяйственную деятельность; его местом в системе экономических связей государства; нормативными параметрами управленческой структуры и пр. Внутренние параметры обусловлены культурно-исторической составляющей, символическим пространством, демографическими характеристиками, сложившейся социально-экономической инфраструктурой, конкретным преломлением нормативно-правовых систем в деятельности управленческой городской элиты и пр.

Несложно принять, что между внешними и внутренними параметрами имеется зависимость, однако, в соответствии с теорией катастроф, «значения внутренних параметров не определяются однозначно значениями внешних» [1, с. 222]. Для выявления в математической модели критических точек, возникающих в процессах такого взаимодействия, вводится понятие теории особенностей, которая доставляет информацию о подобных критических точках. Именно эта информация используется для исследования «катастроф», то есть перескоков системы из одного состояния в другое при изменении параметров.

В качестве примера приведем процесс формирования сетевых структур, обусловленный глобальной сетью Интернет. «В новом, информациональном способе развития источник производительности заключается в технологии генерирования знаний, 
обработки информации и символической коммуникации», - пишет М. Кастельс [4, с. 38]. Но ведь дело не только в «источнике производительности».

Социологи фиксируют процессы децентрализации городов, в ходе которых коренные жители мегаполисов переселяются в периферийные, более благополучные, экологически чистые районы пригорода, предпочитая «городскую жизнь вне города». По Г. Зиммелю, пытаясь именно таким образом «уживаться с внешними силами». Информационные технологии позволяют в ряде случаев работать в виртуальном пространстве, удаленно, не теряя часы, дни и месяцы своей жизни на дорогу. Подобный тренд вносит соответствующие требования к типу жилищ, которые насыщаются достижениями современной информационной техносферы, отвечая также и на экологические запросы жизнедеятельности.

Все эти нововведения в городскую жизнь предъявляют особые требования к подготовке архитекторов в рамках образовательных систем. Соответственно, современного архитектора должны занимать вопросы: что значит мыслить город не только как социокультурный, но и как технический объект? как изобретение Интернета меняет городское пространство и коммуникацию - деловую и повседневную - между людьми? какие социотехнические «точки сборки» формируют ядро устойчивых отношений города? Как влияют эти процессы на пространственные предпочтения жителей города? И многие другие.

Успешная деятельность архитектора связана сегодня с междисциплинарными знаниями, включающими большой круг компонентов, фундирующих его компетентность. Понятие компетентности трактуется весьма неоднозначно. Так, британский психолог Дж. Равен под компетентностью понимает специфические способности, обязательные для действий в определенной предметной области, включающие А) узкоспециальные знания; Б) особого рода предметные навыки, способы мышления; В) осознание ответственности за свои действия на основе ценностей и установок [6]. Мы не можем полностью согласиться с этим перечнем, хотя пункт В) дает определенную свободу интерпретаций. Уж слишком похожа формулировка компетентности в применении к деятельности архитектора на максиму Ле Корбюзье, архитектурного кумира периода функционализма и рационализма 1920-х-1930-х гг.: в соответствии с Афинской хартией жилище должно иметь функции: «спать, мыться, питаться и развлекаться» [5, с. 61].

В арсенале компетенций современного архитектора должны присутствовать те, что формируют целостный, комплексный взгляд на пространство как таковое, и городское, в 
частности. Постижение города как объекта конструирования, как сложной социотехнической системы, требует знания междисциплинарных методологических подходов и владения их инструментарием. Адекватная, непротиворечивая, минимизирующая риски, неизбежно возникающие на пересечении «жизненных миров» в техногенной среде, архитектурно-проектная деятельность требует, помимо узкопрофессиональных знаний, обращение к таким пластам функционирования города, как философия и социология архитектуры, культурно-смысловая составляющая жизни городов, семиотика пространства, метафизические и архетипические основания городской среды, ее ресурсы и социальная динамика, обусловленная миграцией. А также антропологическое понимание города как специфического пространства существования человека, которое конструирует особый смысловой мир, стиль и образ жизни, формирует возможности и векторы социализации и инкультурации.

Город - продукт длительного исторического развития, и это «превращает его в сплав всего комплекса древних и современных смыслов, хранящих в себе отпечаток мировоззренческих установок различных эпох» [8, с. 27]. Например, современная Москва так и не преодолела за три десятка постсоветских лет образа коммунистической утопии «сталинизм въелся в тело Москвы как особая форма мышления и политической организации пространства. Несмотря на череду переименований и перелицовок, сам визуальный облик города остается в значительной степени коммунистическим» [7, с. 198]. «Церетелизация» города лишь закрепила имперские символы столицы. В этом плане актуализируется задача поиска нового архитектурного языка, нового городского кода, в котором была бы заключена современность, содержащая в себе архетипы, идеальные конструкты, лежащие в основе городской культуры и формирующие идентичность горожан, но и образ будущего, воплощающий устремления нации.

О том, что городское пространство - зона особого напряжения, свидетельствует бесконечный ряд дискуссий, ведущихся вокруг разного рода архитектурно-планировочных и нормативно-правовых решений, которые затрагивают жизненные ценности и интересы его жителей. И жители реагируют. В первую очередь, на те решения, которые вторгаются в культурно-историческое «тело» города - прокладка трасс, вырубка парков под застройку со снятием с них статуса особо охраняемых территорий, снос объектов культурного наследия, разрушающих традиционную городскую среду, строительство новых зданий и кварталов в исторических центрах городов. Так, жители московского Лефортова вышли на митинг в связи со строительством Третьего транспортного кольца, и вместо магистрали, 
разрезающей и плотную застройку, и часть старинного парка, был построен дорогостоящий Лефортовский тоннель. Или дискуссия вокруг строительства «Охта-центра» в СанктПетербурге, завершившаяся его отменой. Но как много утрачено!

Разумеется, причины, вызывающие эти проекты и дискуссии, обретения и утраты следствия той же многослойности факторов, что обуславливают саму жизнь городов. И здесь уже речь идет об определении границ неизбежного вторжения в живое пространство города, о балансе между традицией и новацией, не разрушающем столь ценное для горожанина ощущение комфортной идентичности совместного с городом бытия?

Мы далеки от мысли о том, что весь груз ответственности за развитие городов лежит на архитекторе. Но он, как проектировщик, конструктор, дизайнер находится в точке пересечения интересов горожан, управленцев, бизнеса. И в точке пересечения культурноисторических, экономических, производственных, символических и иных векторов городской динамики. Именно он способен, обладая особым типом мышления, предложить решения преобразования уже освоенного урбанистического пространства, вызывающие взаимное доверие разных сторон. Такой - особый тип мышления, проявленный в новых компетенциях, требует особых подходов в подготовке специалистов - и архитекторов, проектировщиков, и управленцев.

В своих работах мы неоднократно подчеркивали, что ценности и установки личности не выводятся из узкопрофессиональной подготовки. Они формируются (если иметь в виду не жизненную среду в целом, а фокусироваться на системе образования) как результат приобщения к философии жизни, глубинного понимания культурных корней осваиваемой среды, способности аккумулировать социально-научное и гуманитарное знание в профессиональной деятельности, видеть (и интегрировать) индивидуальное и социальное в архитектурном проекте. При таком подходе архитектор может быть способен «анализировать тенденции в теории архитектуры ... через призмы множества несводимых друг к другу, часто диаметрально противоположных социологических теорий» [2, с. 114]. И на этой основе давать практический ответ на вызовы современности.

Справедливости ради отметим, что имеет место и обратный процесс - «как скрытая, так и явная интеграция архитектуры в социологическую мысль» [9, p. 40]. Что лишь показывает настоятельную необходимость междисциплинарных методологических подходов к анализу и моделированию сложных систем любого рода.

\section{Библиографический список:}


1. Арнольд В.И. Теория катастроф [Электронный ресурс] // Итоги науки и техники. Серия Современные проблемы математики. Фундаментальные направления. 1986. Т. 5. С. 219277.

http://www.mathnet.ru/links/5272caffffa799fbef55c884d051e0d6/intf41.pdf (дата обращения: 24.11.2019).

2. Делитц Х. Архитектура в социальном измерении // Социологические исследования. 2008. № 10. С. 113-121.

3. Зиммель Г. Большие города и духовная жизнь [Электронный ресурс] // Логос. 2002. № 3 (34).

https://vk.com/doc12814833_285964829?hash=ce9984447ca450fb2f\&dl=efc536274a49b0826f2 2 (дата обращения: 24.11.2019).

4. Кастельс М. Информациональная эпоха: экономика, общество и культура / Пер. с англ. под науч. ред. О.И. Шкаратана. М.: ГУ ВШЭ, 2000.

5. Ле Корбюзье Ш. Три формы расселения. Афинская Хартия / Пер. с фр.; под ред. К.Т. Топуридзе. М.: Прогресс, 1977.

6. Равен Дж. Компетентность в современном обществе: выявление, развитие и реализация. М.: Когито-Центр, 2002.

7. Россман В. В поисках Четвертого Рима: Российские дебаты о переносе столицы. М.: Изд. Дом Высшей школы экономики, 2014. 288 с.

8. Холодная А.А. Культурно-семантическое пространство современного российского города: дисс. ... кандидата культурологии: 24.00.01. М. 2018. 257 с.

9. Delits H. Architectural Modes of Collective Existence: Architectural Sociology as an Comparative Social Theory // Cultural Sociology. 2018. Vol. 12 (1). Pp. 37-57.

\section{Bagdasaryan N.G. Architect in the socio-cultural space of the city}

Based on the thesis of G. Simmel on the need to find an answer to the question about the life of big cities, which lies in the plane of the relationship between the individual and supraindividual content of life, the author discusses the requirements for modern architecture. The city is viewed through the prism of sociality and relevant requirements for the professional characteristics of the architect. The importance of an interdisciplinary approach to the educational process in higher architectural school, the role of socio-philosophical and cultural knowledge is emphasized.

Keywords: Zimmel, social space of the city, competence of the architect, values and attitudes 